\title{
INSIDENS MELASMA DI POLIKLINIK KULIT DAN KELAMIN RSUP DR. M. DJAMIL PADANG TAHUN 2012-2015
}

\author{
Yessy Farina Salim, Satya Wydya Yenny, Sri Lestari
}

\begin{abstract}
Abstrak
Melasma adalah hipermelanosis didapat, mengenai daerah yang sering terpajan sinar matahari. Pada umumnya ditemukan pada wanita usia produktif. Dalam sepuluh tahun terakhir ini belum ada laporan insiden melasma di Poliklinik IK Kulit dan Kelamin RSUP Dr. M. Djamil Padang. Penelitian ini bertujuan mengetahui insidens melasma di Poliklinik Kulit dan Kelamin RSUP Dr. M. Djamil Padang tahun 2012-2015. Penelitian ini menggunakan studi retrospektif dengan pengumpulan data rekam medis pasien baru melasma di Poliklinik Kulit dan Kelamin RSUP Dr. M. Djamil Padang tahun 2012-2015. Diperoleh hasil selama 2012-2015 terdapat 64 kasus melasma (2 laki-laki, 62 perempuan) dari 10.548 kunjungan (insidens 0,61\%); tahun 2012, 2 kasus dari 3186 pasien (0,06\%); tahun 2013,19 kasus dari 2635 pasien (0,71\%); tahun 2014, 20 kasus dari 2571 pasien (0,78\%); tahun 2015; 23 kasus dari 2156 pasien $(1,07 \%)$. Kasus terbanyak ditemukan pada usia 25-44 tahun yaitu 34 kasus. Berdasarkan bentuk klinis, tipe malar 31 kasus, sentrofasial 24 kasus dan tipe mandibular 9 kasus. Pada pemeriksaan lampu Wood didapatkan tipe epidermal 26 kasus, dermal 18 kasus, dan tipe campuran 20 kasus. Dapat disimpulkan, insidens melasma dari tahun 2012-2015 bervariasi setiap tahunnya, kasus terbanyak ditemukan pada perempuan usia 25-44 tahun, klinis terbanyak adalah tipe malar serta tipe epidermal berdasarkan pemeriksaan lampu Wood.
\end{abstract}

Kata kunci: insiden, melasma, malar, epidermal

\begin{abstract}
Melasma is a common acquired symmetric hypermelanosis on sun-exposed skin. It typically affects women of reproductive age. In the last ten years there were no reports of melasma incidence in Dermato-Venereology Outpatient Clinic of Dr. M. Djamil Padang.Aim: To find the incidence of melasma at Dr.M Djamil Hospital Padang since 2012-2015. This research is a retrospective study of melasma at Outpatient Clinic of Dermato-Venereology, by collecting data from the medical record of new patients from January 2012 to December 2015. During 2012-2015 there was 64 cases ( 2 male, 62 female) from 10.548 patients (the incidence was 0, 61\%). In 2012 was 2 cases from 3186 patients (0,06\%); 2013, 19/2635 (0,71\%); 2014, 20/2571 (0,78\%); 2015, 23/2156 (1,07\%). The most cases are found in 25-44 years old, 34 cases. The clinical patterns were malar 31, sentrofacial 24, and mandibular 9 cases. Wood's lamp examination found epidermal type 26, dermal 18, and mixed 20 cases. The result demonstrated the incidences of melasma in 2012-2015 were variable in every year, the most affected was in female 25-44 years old, the most clinical type is malar, and epidermal type from Wood's lamp examination.
\end{abstract}

Keywords: insidence, melasma, malar, epidermal

Affiliasi penulis: Bagian Dermato-Venereologi FK Unand/RSUP M. Djamil Padang

Korespondensi: Yessy Farina Salim email: yessyfarina@gmail.com Telp: 081374305406

\section{Pendahuluan}

Melasma adalah hipermelanosis didapat, berupa bercak yang tidak teratur, berwarna coklat muda sampai coklat tua, dan mengenai daerah yang sering terpajan sinar ultraviolet. ${ }^{1}$ Bercak terlihat di atas bibir, hidung, pipi, dagu, dahi kadang-kadang di leher, dan juga dapat mengenai dada dan bagian dorsal lengan. Melasma biasanya berbentuk iregular, sering berbatas tegas, pigmentasi terang sampai coklat kehitaman. ${ }^{2,3}$

Prevalensi melasma secara pasti belum diketahui. Melasma merupakan penyakit kulit yang umum dijumpai, berkisar antara $0,2-4 \%$ pasien yang berobat di Klinik di Asia Tenggara, dan merupakan gangguan pigmentasi yang paling sering ditemukan pada populasi India.4 Secara epidemiologi, melasma umumnya ditemukan pada ras kulit gelap (tipe kulit Fitzpatrick IV-VI), namun dapat juga ditemukan pada berbagai ras. Melasma lebih sering dijumpai pada ras Hispanik, Asia, dan Amerika Latin dimana masyarakat tinggal di lokasi yang menerima radiasi UV yang tinggi. Melasma ditemukan pada hampir $10 \%$ populasi Amerika Latin. Prevalensi melasma pada wanita hamil di Brazil mencapai 10,7\%. Survey oleh Kohli O dkk. (India, 2014) menunjukkan dari 1500 orang dewasa, gangguan pigmentasi kulit merupakan penyebab utama $23,6 \%$ laki-laki dan $29,9 \%$ perempuan untuk berobat ke dermatologis. ${ }^{4}$

Patogenesis melasma kompleks dan tidak sepenuhnya dipahami. Terdapat berbagai faktor predisposisi melasma, di antaranya yaitu faktor hormonal (melanocyte-stimulating hormone (MSH), 
adrenocorticotropic hormone (ACTH), lipotropin, estrogen, dan progesteron), genetik, penyakit tiroid (hipotiroidisme), dan kehamilan. Paparan sinar UV diduga memiliki peranan penting dalam perkembangan lesi melasma berdasarkan lokasi lesi dan perkembangan gejala pada lesi setelah paparan $\mathrm{UV}^{5}$

Menurut distribusi klinis, lesi melasma dapat dikategorikan menjadi tiga tipe, yaitu tipe sentrofasial, malar, dan mandibular. Tipe sentrofasial ditemukan sebanyak $63 \%$, distribusinya pada dahi, hidung, dagu, dan bibir atas. Tipe malar ditemukan pada hidung dan pipi, sebanyak $21 \%$. Tipe mandibular ditemukan sebanyak $16 \%$, dengan distribusi pada ramus mandibular. Dada anterior dan dorsal lengan dapat juga dikenai. Berdasarkan pemeriksaan lampu Wood, melasma terbagi atas tipe epidermal, dermal, dan campuran. 5,6

Penelitian epidemiologi melasma sudah banyak dilakukan di berbagai negara. Dalam 10 tahun terakhir ini belum ada laporan insiden melasma di Poliklinik IK Kulit dan Kelamin RSUP DR M Djamil Padang.

Penelitian ini bertujuan untuk mengetahui insidens melasma di Poliklinik IK Kulit dan Kelamin RSUP Dr. M. Djamil Padang dari tahun 2012-2015.

\section{Metode}

Penelitian ini merupakan penelitian retrospektif. Data berasal dari rekam medik pasien baru melasma di Poliklinik Kulit dan Kelamin RSUP Dr. M. Djamil Padang periode Januari 2012-Desember 2015. Pada pasien dilakukan pembagian kriteria berdasarkan usia, jenis kelamin, distribusi klinis dan kedalaman lesi berdasarkan pemeriksaan lampu Wood.

\section{Hasil Penelitian}

Sejak Januari 2012-Desember 2015 didapatkan 64 kasus baru melasma (2 laki-laki, 62 perempuan) dari 10.548 total kunjungan pasien di Poliklinik Kulit dan Kelamin RSUP Dr. M. Djamil Padang. Insiden melasma tahun 2012-2014 adalah 0,61\%.

Tabel 1. Jumlah kasus melasma berdasarkan usia dan jenis kelamin di Poliklinik IK Kulit dan Kelamin RSUP Dr. M Djamil Padang tahun 2012-2015

\begin{tabular}{lllll}
\hline Usia & $\begin{array}{l}\text { Laki- } \\
\text { laki }\end{array}$ & Perempuan & Total & $\begin{array}{l}\text { Persen } \\
\text {-tase } \\
(\%)\end{array}$ \\
\hline $15-24$ & 0 & 4 & 4 & 6.25 \\
$25-44$ & 2 & 32 & 34 & 53,13 \\
$45-64$ & 0 & 26 & 26 & 40,62 \\
$>65$ & 0 & 0 & 0 & 0 \\
\hline Total & $\mathbf{2}$ & $\mathbf{6 2}$ & $\mathbf{6 4}$ & $\mathbf{1 0 0}$ \\
\hline
\end{tabular}

Pada tabel 1 terlihat kasus melasma lebih sering dijumpai pada perempuan (62 pasien) dibanding laki-laki (2 pasien). Berdasarkan usia, kasus melasma banyak ditemukan pada usia 25-44 tahun $(53,13 \%)$.

Berdasarkan distribusi klinis, didapatkan tipe malar merupakan distribusi klinis terbanyak $(48,4 \%)$ dibandingkan tipe sentrofasial $(37,5 \%)$ dan mandibular $(14,1 \%)$ seperti yang tampak pada tabel 2 .

Tabel 2. Jumlah kasus melasma berdasarkan distribusi klinis melasma di Poliklinik IK Kulit dan Kelamin RSUP Dr. M Djamil Padang tahun 2012-2015

\begin{tabular}{lll}
\hline $\begin{array}{l}\text { Distribusi } \\
\text { melasma }\end{array}$ & Total & Persentase (\%) \\
\hline Malar & 31 & 48,4 \\
Sentrofasial & 24 & 37,5 \\
Mandibular & 9 & 14,1 \\
\hline Total & $\mathbf{6 4}$ & $\mathbf{1 0 0}$ \\
\hline
\end{tabular}

Tabel 3. Jumlah kasus melasma berdasarkan pemeriksaan lampu Wood di Poliklinik IK Kulit dan Kelamin RSUP Dr. M Djamil Padang tahun 2012-2015

\begin{tabular}{lll}
\hline Tipe melasma & Total & Persentase (\%) \\
\hline Epidermal & 26 & 40,63 \\
Dermal & 18 & 28,12 \\
Campuran & 20 & 31,25 \\
Indeterminate & 0 & 0 \\
\hline Total & $\mathbf{6 4}$ & $\mathbf{1 0 0}$
\end{tabular}

Pada tabel 3, terlihat tipe epidermal $(40,63 \%)$ merupakan tipe terbanyak ditemukan berdasarkan pemeriksaan lampu Wood dibandingkan tipe dermal, campuran dan indeterminate.

\section{Pembahasan}

Terdapat hubungan yang penting antara melasma dan jenis kelamin. Sebagian besar penelitian epidemiologi melasma melaporkan peningkatan persentase melasma pada perempuan dibandingkan laki-laki dengan rasio 7-9:1. Perbandingan melasma antara perempuan dan laki-laki di Indonesia yaitu 24:1, paling sering ditemukan pada perempuan usia subur berusia 30-44 tahun dengan riwayat terpapar langsung sinar matahari. ${ }^{7}$ Achar A dkk. (India, 2011) melaporkan epidemiologi melasma pada 312 pasien didapatkan rasio perempuan dan laki-laki 4:1 dengan umur 14-54 tahun dengan rata-rata 33,45 tahun. ${ }^{8}$

Umborowati MA dkk. (Surabaya, 2014) melaporkan dari 1.313 pasien melasma, hampir seluruh pasien berjenis kelamin perempuan (99,2\%), kecuali 3 pasien berjenis kelamin laki-laki $(0,8 \%){ }^{7}$ Rizal Y (Padang, 2008) melaporkan insiden melasma di Poliklinik Kulit dan Kelamin RSUP Dr. M. Djamil Padang periode 2001-2006, didapatkan 405 pasien melasma (8 laki-laki, 397 perempuan) dari 56.067 kunjungan. ${ }^{9}$ Pada penelitian ini ditemukan kejadian melasma lebih banyak pada perempuan dibandingkan laki-laki dengan rentang usia 25-44 tahun.

Berdasarkan pola distribusi melasma diklasifikasikan menjadi tipe malar, sentrofasial, dan mandibular. Handel AC dkk. (Brazil, 2014) melaporkan tipe sentrofasial merupakan tipe terbanyak ditemukan dibandingkan malar dan mandibular. ${ }^{10}$ Hasil yang sama juga dilaporkan sebelumnya oleh Achar A dkk. di India pada tahun 2011.8 Hasil penelitian-penelitian tersebut berbeda pada penelitian ini, dimana ditemukan tipe malar $(48,4 \%)$ merupakan tipe yang paling banyak ditemukan. 
Dengan pemeriksaan lampu Wood dapat dibedakan letak peningkatan melanin, di epidermis, dermis, atau keduanya. Jika pada pemeriksaan lampu Wood kelainan semakin jelas dan dengan peregangan kulit menjadi lebih terang maka lokasi pigmen di epidermis, sedangkan lokasi pigmen di dermis jika tidak terjadi perubahan, baik dengan pemeriksaan lampu Wood maupun dengan peregangan kulit. ${ }^{1}$ Nahidi dkk. (Iran, 2013) melakukan penelitian hubungan klinis dan epidemiologi pada melasma, berdasarkan pemeriksaan lampu Wood dilaporkan tipe epidermal adalah tipe yang paling banyak ditemukan (44\%). ${ }^{11}$ Pada penelitian ini didapatkan hasil yang sama, dimana tipe epidermal merupakan tipe yang paling banyak ditemukan sebesar $(40,63 \%)$.

\section{Simpulan}

Insidens melasma dari tahun 2012-2015 bervariasi setiap tahunnya, kasus terbanyak ditemukan pada perempuan usia 25-44 tahun, klinis terbanyak adalah tipe malar serta tipe epidermal berdasarkan pemeriksaan lampu Wood.

\section{Daftar Pustaka}

1. Lapeere H, Boone B, De Schepper S, Verhaeghe $\mathrm{E}$, Ongenae K, Van Geel N, et al. Hypomelanoses and hypermelanoses. In: Wolff K, Goldsmith LA, Katz SI, Gilchrest BA, Paller AS, Leffel DJ, editors. Fitzpatrick Dermatology in General Medicine. Ed $8^{\text {th }}$. New York: McGraw Hill; 2012: 805-25.

2. Passeron T. Melasma pathogenesis and influencing factors - an overview of the latest research. JEADV. 2013; 27:5-6.

3. Lee AY. An updated review of melasma pathogenesis. Dermatologica Sinica. 2014; 32:233-39.

4. Kohli M, Sharad J, Ganjoo A, Kandhari S, Mysore VR. A cross-sectional, multicentric clinicoepidemiological study of melasma in India. Dermatol Ther (Heidelb). 2014; 4:71-81.

5. Kayva M. Melasma: a clinico-epidemiological study. International Journal of Basic and Applied Medical Sciences. 2014; 4(2):388-391.

6. Shankar K, Godse K, Aurangabadkar S, Lahiri K, Mysore V, Ganjoo A, Vedamurty M, et al. Evidence-based treatment for melasma: expert opinion and a review. Dermatol Ther (Heidelb). 2014; 4:165-186.

7. Umborowati MA, Rahmadewi. Studi retrospektif: Diagnosis dan terapi pasien melasma. Periodical of Dermatology and Venereology. 2014; 26:5663.

8. Achar A, Rathi SK. Melasma: a clinicoepidemiological study of 312 cases. Indian J Dermatol. 2011; 56(4):380-382.

9. Rizal Y, Lestari S. Insidens melasma di Poli Kulit dan Kelamin RSUP Dr. M. Djamil Padang tahun 2001-2006. Media Dermato-Venereologica Indonesiana. 2008; 35:56-9.
10. Handel AC, Miot LD, Miot HA. Melasma: a clinical and epidemiological review. An Bras Dermatol. 2014; 89(5): 771-782.

11. Nahidi $Y$, Meibodi NT, Layegh $P$, Esmaeeli $H$, Hosseini FS. Evaluation of the relationship between clinicoepidemiological features of melasma and the level of involvement on wood's lamp examination. Iran J Dermatol. 2013; 16:5763. 